University of San Diego

Digital USD

Spring 5-21-2018

\title{
Effect of Adult Chemical Cues on Molting of Fiddler Crab Megalopae in Low Salinity Seawater
}

Sydney Rilum

University of San Diego

Follow this and additional works at: https://digital.sandiego.edu/honors_theses

Part of the Behavior and Ethology Commons, Biology Commons, and the Marine Biology Commons

\section{Digital USD Citation}

Rilum, Sydney, "Effect of Adult Chemical Cues on Molting of Fiddler Crab Megalopae in Low Salinity Seawater" (2018). Undergraduate Honors Theses. 58.

https://digital.sandiego.edu/honors_theses/58

This Undergraduate Honors Thesis is brought to you for free and open access by the Theses and Dissertations at Digital USD. It has been accepted for inclusion in Undergraduate Honors Theses by an authorized administrator of Digital USD. For more information, please contact digital@sandiego.edu. 
Effect of Adult Chemical Cues on Molting of Fiddler Crab Megalopae in Low Salinity Seawater

\author{
A Thesis \\ Presented to \\ The Faculty and the Honors Program \\ Of the University of San Diego
}

By

Sydney Celeste Rilum

Environmental \& Ocean Sciences

2018 
Effect of Adult Chemical Cues on Molting of Fiddler Crab Megalopae in Low Salinity Seawater Sydney C. Rilum ${ }^{1,2}$, Kathleen A. Reinsel2,3, James M. Welch ${ }^{2,3}$

${ }^{1}$ Dept. of Environmental \& Ocean Sciences, University of San Diego, San Diego, CA 92110

${ }^{2}$ Nicholas School of the Environment, Duke University Marine Laboratory, Beaufort, NC 28516

${ }^{3}$ Dept. of Biology, Wittenberg University, Springfield, OH 45502

\section{ABSTRACT}

Three species of fiddler crabs, Uca minax, U. pugnax, and U. pugilator, are commonly found in estuaries along the Atlantic coast, each with distinct adult habitats differing in salinity and sediment grain size. Prior research has found evidence for larvae exhibiting selective settlement; however, the degree to which and the method by which they choose their speciesappropriate habitat to settle in is still unknown. Additionally, a recent study determined that chemical cues from adult crabs stimulate molting in field-caught fiddler crab megalopae, as previously determined in lab-reared megalopae; however, in 35 ppt seawater, few $U$. minax molted. This study tested the hypotheses that 1) chemical cues from adult fiddler crabs would stimulate molting of conspecific megalopae in $10 \mathrm{ppt}$ seawater, and 2) that at $10 \mathrm{ppt}$, more $U$. minax would molt than at $35 \mathrm{ppt}$. Adult chemical cues accelerated molting in field-caught megalopae of $U$. pugilator and $U$. pugnax, which both molted significantly earlier in all odor water treatments than in the control water, and fastest in conspecific water. U. pugilator megalopae were stimulated to molt in all treatments, whereas $U$. pugnax molted mostly in conspecific odor. However, even at $10 \mathrm{ppt}$, few U. minax molted and there were no differences in molting frequency or time among treatments. The few $U$. minax molts suggest that these experimental conditions may still not be ideal, and other factors may be responsible for stimulating and accelerating their molting and settlement site selection. 


\section{INTRODUCTION}

In North Carolina and estuaries along the Atlantic coast of the United States, three species of fiddler crabs (genus $U c a$ ) are commonly found. These three species (Uca minax, Uca pugilator and Uca pugnax) share a common larval life history, in which near high tide at night, female adults release zoeae that then swim to the surface and are carried out of the estuary on ebb tides (Epifanio 1988, De Vries et al. 1994). Once in offshore waters, zoeae develop into megalopae before returning to the estuary using flood tide transport where they settle and further develop into juvenile crabs (Epifanio 1988, De Vries et al. 1994). Although morphologically similar as larvae, the adults differ in appearance and by the estuarine habitats in which they live. $U$. minax inhabit low salinity areas of salt marshes, $U$. pugnax inhabit moderate to high salinity salt marshes with muddy sediments, and $U$. pugilator inhabit moderate to high salinity sandflats and sandy regions of salt marshes (Teal 1958, Miller \& Maurer 1973, Crane 1975).

Fiddler crabs serve a vital role to salt marsh ecosystems, as they feed on decaying plant material in the sediment and are an important link in the food web, preyed upon by herons, egrets, ibises, and blue crabs (Crane 1975, Petit \& Blidstein 1987, Zhong 2006). When they consume algae and other organic matter in the sediment by sifting through the surface sediment, fiddler crabs aid in redistributing nutrients in the salt marsh (Zhong 2006, Smith \& Green 2015). In addition, fiddler crabs are bioturbators that improve salt marsh quality by redistributing oxygen in the sediment, enhancing plant growth, and allowing for the retention of meiofauna when they construct burrows for protection and mating (Christy 1983, Frix et al. 1991, Qureshi \& Saher 2012, Bolton et al. 2013).

Prior research has provided evidence that suggests that larvae exhibit selective settlement (O’Connor 1993, Brodie et al. 2005, Welch et al. 2015), however, it is still uncertain how larvae 
choose their species-appropriate habitat to settle in. Determining the mechanisms used in fiddler crab species-specific habitat selection, as well as their ideal molting conditions, can aid in understanding community composition and predicting the species of settlers in habitats with varying salinity, sediment grain size and adult species present. Additionally, since fiddler crabs can be used as environmental indicators for contaminants, such as insecticides, understanding their habitat selection mechanisms can also aid in assessing the health of salt marsh ecosystems (Zhong 2006).

Previous studies suggest that chemical cues given off by settlement sites stimulate molting of megalopae by possibly indicating a proper habitat (Wolcott \& De Vries 1994). For example, sediment from adult habitats (Christy 1989) and water containing adult crabs have both individually and jointly stimulated molting of $U$. pugilator (O'Connor 1991). Similarly, for $U$. pugnax, seawater conditioned by adult crabs (O’Connor \& Gregg 1998), extracts of adult crabs (O’Connor 2005), and sediment conditioned by adult crabs (O'Connor \& Van 2006) have also stimulated metamorphosis. Additionally, field experiments have determined that molting of either $U$. pugnax or $U$. minax megalopae is accelerated when placed in adult salt marsh habitats and experience a rapidly diminishing effect the further away they are from the adult habitat (O’Connor \& Judge 1997, 1999, 2004). Although the results from these studies have provided much support for habitat cues stimulating the molting of fiddler crab megalopae, they were all conducted using laboratory-reared megalopae from known-species adults. Once molecular techniques were discovered and implemented, species identification of field-caught fiddler crab megalopae became possible (Behum et al. 2005, Welch et al. 2015), and research has thus been capable of executing additional field experiments in studying fiddler crab larval development. 
A recent study used field-caught $U c a$ megalopae to determine whether cues from adult fiddler crabs stimulate molting, as they do for laboratory-reared megalopae, and determined that field-caught Uca megalopae are stimulated to molt by conspecific odors (Welch et al. 2016). This study was repeated in the summer of 2016 at the Duke University Marine Lab at 20 ppt to determine whether $U$. minax would molt more frequently in reduced salinity water, as compared to the initial experiment done at $35 \mathrm{ppt}$. However, only a few more $U$. minax molted at $20 \mathrm{ppt}$, and very late in the 10-day experimental period. This may imply that the conditions were not ideal for them, as $U$. minax tend to inhabit the lower salinity regions of salt marshes (Teal 1958).

Although research has been carried out on molting and larval development of fiddler crabs, research focused on the impact of salinity on molting has not occurred. Nevertheless, research has been conducted on effects of salinity on larval development of other crabs. For instance, a study on the larval development of blue crab Callinectes sapidus Rathbun, reared in the laboratory, determined that $C$. sapidus molts to the first crab stage earlier in $26.7 \mathrm{ppt}$ than in $20.1 \mathrm{ppt}$ and $31.1 \mathrm{ppt}$ at $25^{\circ} \mathrm{C}$ (Costlow \& Bookhout 1959). Larvae maintained at $20.1 \mathrm{ppt}$ and $26.7 \mathrm{ppt}$ had similar durations of the megalopa stage (6-9 days), compared to higher salinities at 31.1 ppt with longer time to molt periods of 10-20 days (Costlow \& Bookhout 1959). Megalopae of the mud crab Panopeus herbstii, reared in the laboratory, molted similarly in $20.1 \mathrm{ppt}, 26.5$ ppt, and $31.1 \mathrm{ppt}$ waters, while none survived to molt in $12.5 \mathrm{ppt}$ water (Costlow et al. 1962). Additionally, both zoeae and megalopae experienced delays in molting at 20.1 ppt water (Costlow et al. 1962). Similar research conducted with lab-reared Rhithropanopeus harrisii crab larvae discovered the highest percentages of survival and molting of megalopae to the first crab stage at $20^{\circ} \mathrm{C}$ in $15 \mathrm{ppt}$ and $25 \mathrm{ppt}$ and at $25^{\circ} \mathrm{C}$ in $15 \mathrm{ppt}$ (Costlow et al. 1966). However, these salinity-temperature combinations required the greatest time for molting, as compared to other 
combinations with shorter molting times and lower survival percentages (Costlow et al. 1966). These studies involving different crab genera bring to the forefront the need and importance to conduct similar research on fiddler crabs and determine if they are similarly affected by varied salinity.

This study repeats the experiment conducted in Welch et al. (2016), but at $10 \mathrm{ppt}$ estuarine water, and aims to determine whether $U$. minax megalopae molt more frequently in the reduced salinity estuarine water than in the experiments conducted at $35 \mathrm{ppt}$ and $20 \mathrm{ppt}$. The study also seeks to determine how salinity affects the molting stimulation of the other two species, U. pugilator and U. pugnax. Another goal of conducting the Welch et al. (2016) study at $10 \mathrm{ppt}$ is to determine the importance of salinity and chemical cues produced by adult fiddler crabs on settlement site selection by fiddler crab megalopae. It is hypothesized that U. minax would molt more frequently and earlier in the 10-day experimental period than in the previous experiments carried out in $35 \mathrm{ppt}$ and $20 \mathrm{ppt}$.

\section{MATERIALS AND METHODS}

\section{Field collection of megalopae and adult fiddler crabs}

Fiddler crab megalopae were collected with a 0.75 m diameter $333 \mu \mathrm{m}$ mesh plankton net, deployed from a platform under the Pivers Island Bridge in Beaufort, North Carolina, USA $\left(34^{\circ} 43.20^{\prime} \mathrm{N}, 76^{\circ} 40.40^{\prime} \mathrm{W}\right)$, for each of five experiments conducted from June to August 2017. Plankton nets were deployed for 45 minutes surrounding the time of maximum nocturnal flood current, since fiddler crab megalopae utilize flood tide transport to travel upstream into estuarine habitats (DeVries et al. 1994, Forward \& Tankersley 2001). Uca megalopae were separated from the other organisms collected in the net sample and held in 20 ppt estuarine water for $\sim 8-12$ 
hours, to transition them from 35 ppt estuarine water to 10 ppt estuarine water used in this study. Estuarine water (salinity ranging from 33-35 ppt) was collected by bucket off a dock at Duke University Marine Lab and filtered through a $5 \mu \mathrm{m}$ bag filter before being diluted with deionized water to 20 ppt or 10 ppt.

Adult U. pugilator were collected from a sandflat in the Rachel Carson Estuarine Research Reserve $\left(34^{\circ} 42.71^{\prime} \mathrm{N}, 76^{\circ} 40.47^{\prime} \mathrm{W}\right)$ and adult $U$. minax and $U$. pugnax were collected from Bell Creek Salt Marsh (34 $47.39^{\prime}$ N, $76^{\circ} 40.14^{\prime}$ W). Collected fiddler crabs were maintained in large tanks in Lab 4 at the Duke University Marine Lab. They were given running seawater (salinity $=34 \mathrm{ppt}$ ) and sediment from their collection site, which was periodically added to the tanks, serving as fresh food for the crabs. U. pugilator were held separately in a rectangular tank $(122 \mathrm{~cm} \times 70 \mathrm{~cm} \times 30 \mathrm{~cm})$, while $U$. minax and $U$. pugnax were held together in a large circular tank (122 cm diameter, $60 \mathrm{~cm}$ depth). Groups of each of the species of fiddler crabs were used in lab each day and returned to their holding tanks following usage in odor water preparation. More crabs were collected and held than needed to ensure that different groups of crabs were used to prepare the odor waters each day. Adult fiddler crabs were released back to their appropriate habitat at the conclusion of the experiment.

\section{Odor water preparation}

Species-specific odor waters were prepared each day during the experiments. Estuarine water was collected off the dock at Duke University Marine Lab, filtered through a $5 \mu \mathrm{m}$ bag filter, and diluted to $10 \mathrm{ppt}$ with deionized water. The prepared $10 \mathrm{ppt}$ estuarine water served as the control water treatment for the experiments. Approximately 25 grams of each species of adult fiddler crabs were soaked in $500 \mathrm{ml}$ of the prepared $10 \mathrm{ppt}$ seawater for 1 hour in speciesspecific $2800 \mathrm{ml}$ Erlenmeyer flasks. The estuarine water was aerated during the hour of soaking. 
After one hour, each of the odor waters was filtered through a $500 \mu \mathrm{m}$ sieve into species-specific beakers to remove any particles left by the crabs during the incubation period. The sieve was rinsed with warm tap water then deionized water between uses.

\section{Experimental set-up}

For each of the five 10-day experiments, individual megalopae were placed into separate $20 \mathrm{ml}$ scintillation vials containing $10 \mathrm{ml}$ of one of the four water treatments. Vials were arranged in an $8 \times 8$ array, in two groups of 64 for a total of 128 vials. The water treatments were systematically varied in each row. The vials were kept at $25^{\circ} \mathrm{C}$ with ambient 14 hour light:10 hour dark cycle for a period of 10 days. Each day, megalopae were transferred, using a glass wide bore pipet, to clean vials with newly prepared water to prevent degradation of the chemical cues. Megalopae were fed recently hatched Artemia nauplii daily, after receiving a water change, and monitored four times per day, at 06:30, 11:00, 17:30 and 23:00 hours. Megalopae found molted or dead at each observation period were preserved in $95 \%$ ethanol for later species identification and date and time were recorded. During the last observation period on day 10, the remaining megalopae were preserved for species identification.

\section{Uca species identification}

Each of the preserved $U c a$ megalopae and juveniles species was identified using the method of Welch et al. (2015). DNA was extracted from each individual (Estoup et al. 1996), followed by multiplex PCR. Gel electrophoresis was used to identify the species of each individual based on the number of base pairs displayed in the amplified ITS157 gene (Welch $e t$ al. 2015). 


\section{Data analysis}

The average time to molt in each odor water treatment for $U$. pugilator and $U$. pugnax species was compared with separate 1-way ANOVAs (Sokal \& Rohlf 1981), and individual treatments were compared with Tukey post-hoc tests using SPSS 13. Since $U$. minax megalopae only had average time to molt data in two odor water treatments, the times to molt were compared using a $t$-test (Sokal \& Rohlf 1981). A $z$-test for proportions (Walpole 1974) was used to compare the proportions of the megalopae that molted in each water treatment with the proportions that molted in the control treatment, as well as in the other water treatments, for each species.

\section{RESULTS}

Megalopae of the three fiddler crab species were evenly distributed across the four water treatments (Table 1). A total of 623 megalopae, consisting of 98 U. pugilator, 340 U. pugnax, and $185 U$. minax, were tested and identified over five experimental periods (Table 2). There were 9 megalopae omitted from the results and data analysis, as they could not be identified due to failed amplification of DNA in PCR. Of the unidentified larvae, four had died, two remained megalopae, and three had molted. Of the identified larvae, $33.1 \%$ molted, $62.3 \%$ remained megalopae, and $4.6 \%$ died (Table 2).

A majority of the megalopae molted during days 3-6 of the 10-day experimental period. The shortest average time to molt (91.79 hours, ranging from 65 to 227 hours) for $U$. pugilator megalopae occurred in their own species-specific odor water, which was significantly earlier than in the control water (U. pugilator: ANOVA, $\mathrm{F}_{3,75}=5.522, \mathrm{p}<0.01$; Fig. 1a). Similarly, for U. pugnax, the shortest average time to molt (103.94 hours, ranging from 43 to 227 hours) was 
observed in their conspecific odor water, which was also significantly earlier than in the control water (U. pugnax: ANOVA, $\mathrm{F}_{3,106}=4.722, \mathrm{p}<0.01$; Fig. $\left.1 \mathrm{~b}\right)$. Few $U$. minax molted in this study, and those that did molted in the conspecific water and $U$. pugnax water, except for one $U$. minax that molted in the control water treatment (Fig. 1c). The shortest time to molt for $U$. minax (71.88 hours) was in the control water treatment; however, it was of no statistical significance and thus not possible to determine if there was a significant difference between the average time to molt in the control water versus the other two water treatments (Fig. 1c). The majority of $U$. minax that molted did so in their own species-specific odor water treatment (12 individuals), with an average time to molt of 126.56 hours, ranging from 60 to 235 hours (Fig. 1c). There was not a significant difference between the average time to molt in the $U$. pugnax and $U$. minax odor waters $\left(t_{3}=0.21 ; \mathrm{p}=0.85\right)$. No $U$. minax megalopae molted in $U$. pugilator odor water (Fig. 1c).

Molting was observed in all water treatments for $U$. pugilator, and significantly more with crab odor than without, with $95.0 \%$ in $U$. pugilator, $92.6 \%$ in $U$. pugnax, and $85.71 \%$ in $U$. minax (Fig. 2a). However, there was no significant difference in the percent of molting between the three odor water treatments. Additionally, all but one $U$. pugilator that were placed in the $U$. pugilator water treatment molted (Fig. 2a). U. pugnax also molted in each of the water treatments, with a significantly largest percent of molting in their conspecific odor water treatment (89\%, Fig. 2b). Unlike U. pugilator, U. pugnax had significantly lower percent molting in the other two odor water treatments, with no significant difference between the $U$. minax and control treatments (Fig. 2b). Few (16 out of 185, 8.65\%) U. minax megalopae molted in any water treatment during the experiments, with no molting observed in the $U$. pugilator odor water (Fig. 2c). Of the water treatments $U$. minax molted in, the highest percent of molting (25.5\%) 
occurred in their conspecific odor water, which was statistically more than in the control or $U$. pugilator treatments but not statistically different from U. pugnax odor water (Fig. 2c).

\section{DISCUSSION}

The results of this study indicate that chemical cues accelerate molting in conspecific odor waters for $U$. pugilator and $U$. pugnax. Both $U$. pugilator and $U$. pugnax molted significantly earlier in their conspecific odor water treatment, which was significantly different from the control water but not from the other two odor water treatments. Due to insufficient data, acceleration conclusions are unclear for $U$. minax, as not enough molted in the control water treatment to determine if there was a significant difference in molting time in the $U$. minax and U. pugnax waters.

The results of this study also support the hypothesis that chemical cues stimulate molting of field-caught megalopae, but differently for each species. U. pugilator molted significantly more in all three odor water treatments than in the control water, but not significantly more in its own species-specific odor water than the other two odor treatments. Since molting was observed in all water treatments for $U$. pugilator, this indicates that they may be relatively unselective on where they settle. In contrast, U. pugnax was highly selective in the water they molted in. They molted significantly more in their own conspecific water than in any other water treatment, indicating that they prefer to molt in areas that already have $U$. pugnax adults present. Finally, $U$. minax were not significantly stimulated to molt by an odor water treatment, as still few $U$. minax molted in 10 ppt water. However, more total $U$. minax molted in their conspecific water in this study at 10 ppt seawater than in the 35 ppt experiment (Welch et al. 2016). 
Since U. minax did not molt more frequently in this study as hypothesized, it indicates that these experimental conditions may still not be ideal and other factors besides salinity may stimulate and accelerate their molting. One reason $U$. minax may not have had a high percentage of molting is because they may require more time to molt than the 10-day experimental period under these conditions. This may be a probable reason because U. minax inhabit the upper portion of the marsh, meaning that it may take longer for them to reach their species appropriate habitat than the other two species, and thus require a longer time to molt (Teal 1958). Another reason could be that $U$. minax respond better to habitat cues, such as from the sediment or Spartina cord grass, than adult crab odor chemical cues. Sediment from adult habitats has stimulated molting in $U$. pugilator and $U$. pugnax species in previous studies, however, have not been explicitly tested with $U$. minax species in a lab setting (Christy 1989, O'Connor \& Van 2006). Another alternative is that $U$. minax may need a stronger chemical cue concentration in order to be stimulated to molt. For instance, the odor water prepared by soaking $\sim 25 \mathrm{~g}$ of adult crabs may not be an ideal concentration for molting stimulation in $U$. minax as it is for the other two species. Instead, they may require a larger number of crabs soaking in the same amount of seawater to receive the same effect. Future research should thus focus on the mentioned factors not accounted for in this study to determine the most ideal molting and habitat selection conditions for $U$. minax. Once determined, this information could aid in assessing salt marsh ecosystem health by predicting community composition under various environmental conditions that impact fiddler crab molting, and thus their presence, in the marsh. 


\section{TABLES}

Table 1. Number of megalopae of each $U c a$ species tested in each odor treatment.

\begin{tabular}{|l|c|c|c|}
\hline Treatment & U.pugilator & U.pugnax & U.minax \\
\hline Control & 20 & 87 & 49 \\
\hline U. pugilator odor & 20 & 86 & 50 \\
\hline U. pugnax odor & 29 & 87 & 39 \\
\hline U. minax odor & 29 & 80 & 47 \\
\hline
\end{tabular}

Table 2. Number and percentages of megalopae, of each Uca species, that molted, remained megalopae or died during the experiment. Unidentified megalopae omitted.

\begin{tabular}{|l|c|c|c|c|}
\hline Species & $\begin{array}{c}\text { Total } \\
\text { Tested }\end{array}$ & $\begin{array}{c}\text { Number } \\
\text { molted }\end{array}$ & $\begin{array}{c}\text { Number } \\
\text { remained } \\
\text { megalopae }\end{array}$ & $\begin{array}{c}\text { Number } \\
\text { died }\end{array}$ \\
\hline U. pugilator & 98 & $80(81.6 \%)$ & $15(15.3 \%)$ & $3(3.1 \%)$ \\
\hline U. pugnax & 340 & $110(32.3 \%)$ & $211(62.1 \%)$ & $19(5.6 \%)$ \\
\hline U. minax & 185 & $16(8.6 \%)$ & $162(87.6 \%)$ & $7(3.8 \%)$ \\
\hline Total & 623 & $206(33.1 \%)$ & $388(62.3 \%)$ & $29(4.6 \%)$ \\
\hline
\end{tabular}




\section{FIGURES}

Figure 1. Mean time to molt ( \pm SE) in hours for megalopae of (a) Uca pugilator, (b) U. pugnax, and (c) U. minax exposed to estuarine seawater (control) or seawater treatments with different adult chemical cues. Numbers in bars represent the total number of megalopae that molted in each treatment. Lowercase letters above error bars indicate treatments that did not differ by Tukey post-hoc tests.

Figure 2. Percent of megalopae of (a) Uca pugilator, (b) U. pugnax, and (c) U. minax that molted (dark bars) and did not molt (light bars) during 10 days of exposure to estuarine seawater (control) or seawater treatments with adult chemical cues. Different lowercase letters indicate statistically significant differences in percent molting by z-test for proportions. Megalopae that died during the experiments were excluded from analysis. 
Figure 1.

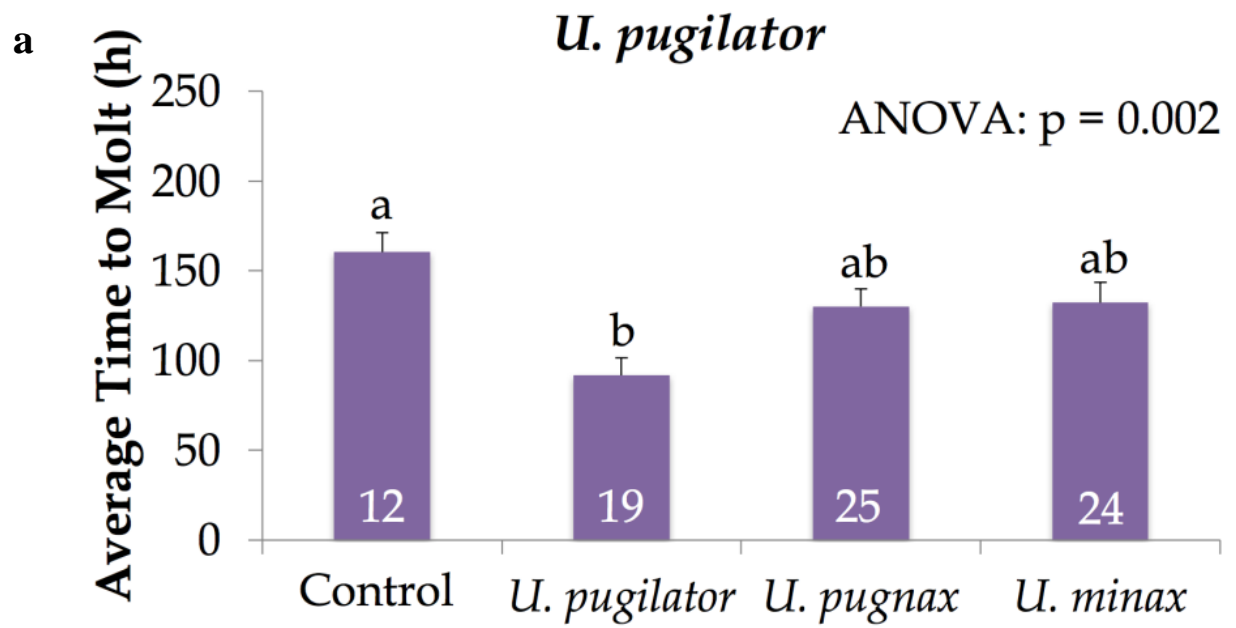

b

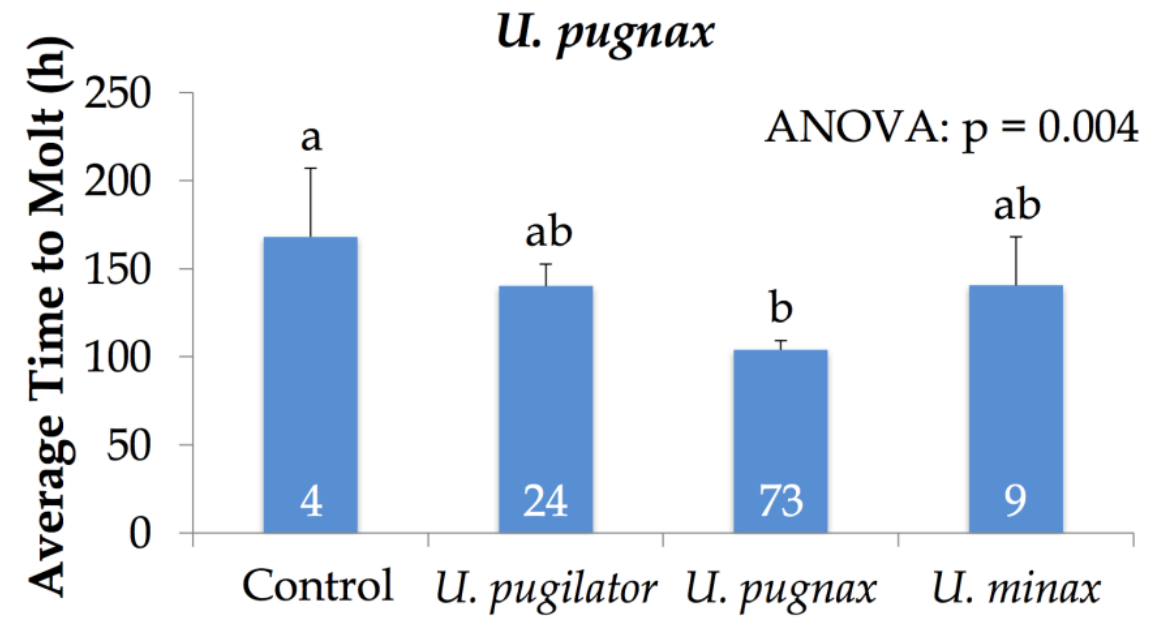

c

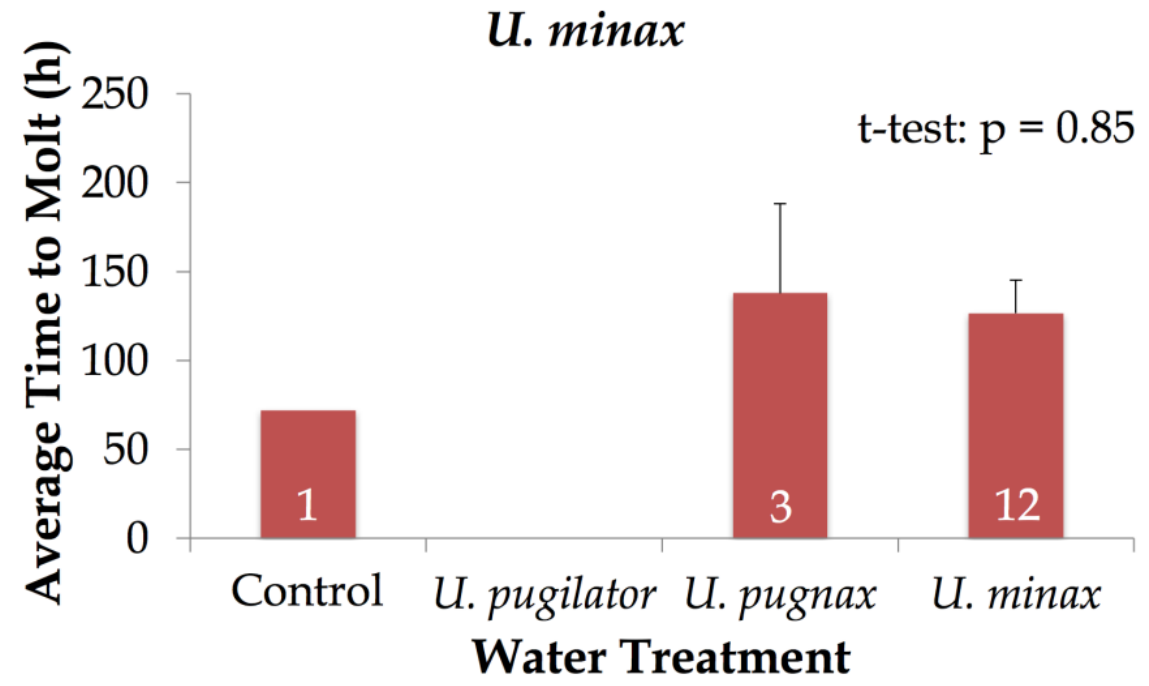


Figure 2.

a

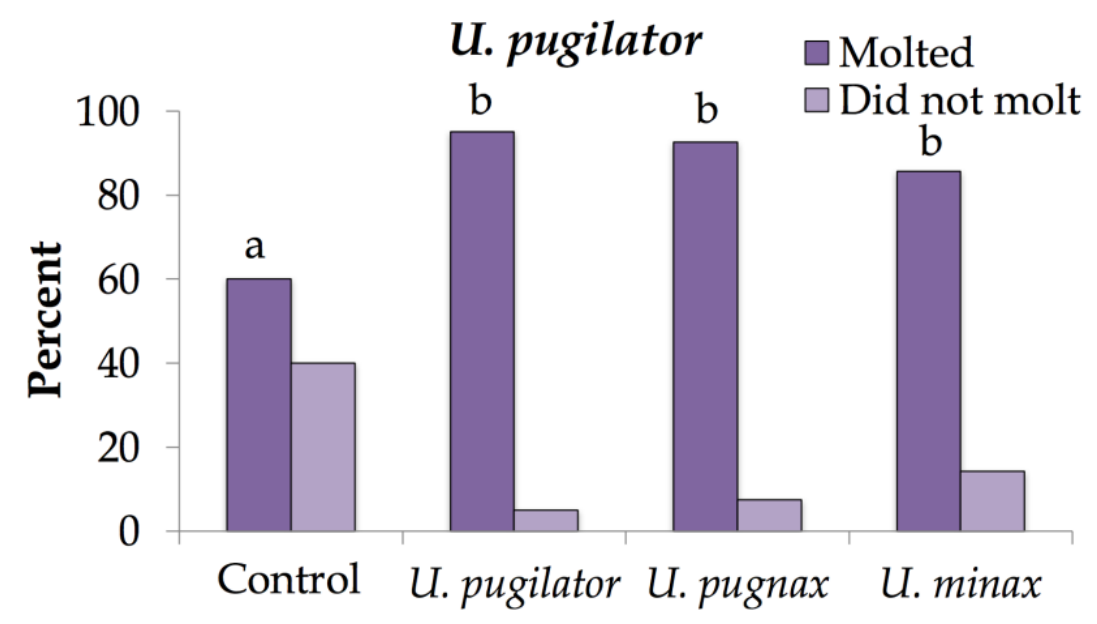

b

U. pugnax

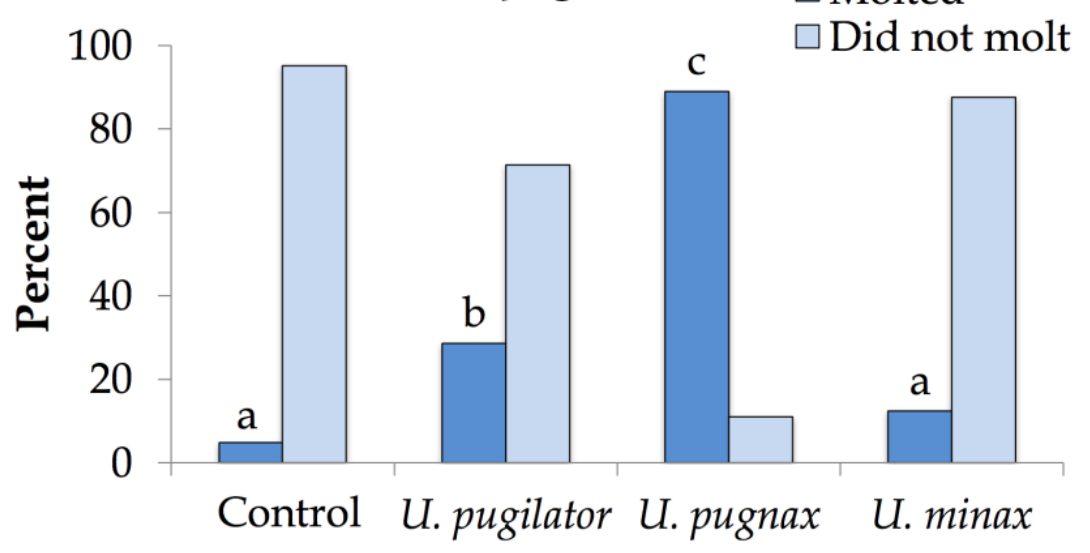

c

U. minax

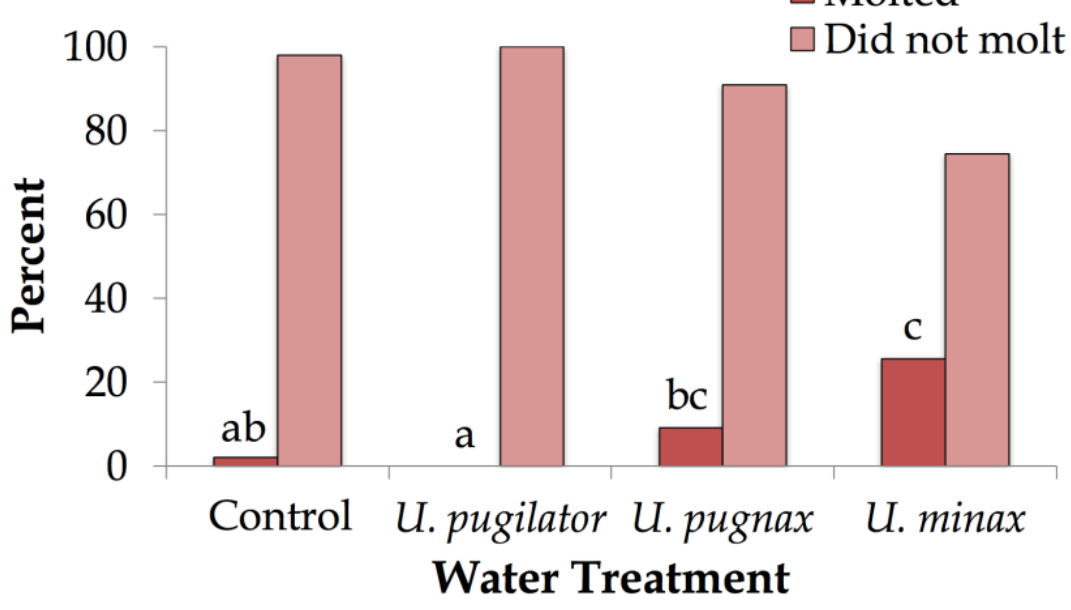




\section{ACKNOWLEDGEMENTS}

This study was funded in part by the National Science Foundation Grant \#OCE-1460180. We thank R. Forward for the use of his laboratory and equipment at the Duke Marine Laboratory, T. Shultz for access to the Molecular Facility, N. McKim, A. Vega, and Z. Wong for their assistance in adult fiddler crab collection, and N. Reyns for her supportive advisement.

\section{LITERATURE CITED}

Behum, M. E., Brodie, R. J., \& Staton, J. L. (2005). Distribution of juvenile Uca pugnax and $U$. pugilator across habitats in a South Carolina estuary, assessed by molecular techniques. Marine Ecology Progress Series, 288, 211-220.

Bolton, J., Backwell, P. R. Y., \& Jennions, M. D. (2013). Density dependence and fighting in species with indeterminate growth: a test in a fiddler crab. Animal Behaviour, 85(6), 1367-1376.

Brodie, R. J., Behum, M. E., Monroe, E., Glenn, N., \& Staton, J. L. (2005). Recruitment to adult habitats following marine planktonic development in the fiddler crabs, Uca pugilator, $U$. pugnax, and U. minax. Marine Biology, 147(1), 105-111.

Christy, J. H. (1983). Female choice in the resource defense mating system of the sand fiddler crab, Uca pugilator. Behavioral Ecology and Sociobiology, 12, 169-180.

Christy, J. H. (1989). Rapid development of megalopae of the fiddler crab Uca pugilator reared over sediment: implications for models of larval recruitment. Marine Ecology Progress Series, 57, 259-265.

Costlow, J. D. (1967). The effect of salinity and temperature on survival and metamorphosis of megalops of the blue crab Callinectes sapidus. Bio Med Central, 15(1), 84-97. 
Costlow, J. D., \& Bookhout, C. G. (1959). The Larval Development of Callinectes sapidus Rathbun Reared in the Laboratory. The Biological Bulletin, 116(3), 373-396.

Costlow, J. D., Bookhout, C. G., \& Monroe, R. (1962). Division of Comparative Physiology and Biochemistry, Society for Integrative and Comparative Biology Salinity-Temperature Effects on the Larval Development of the Crab, Panopeus herbstii Milne-Edwards, Reared in the Laboratory. Physiological Zoology, 35(1), 79-93.

Costlow, J. D., Bookhout, C. G., \& Monroe, R. J. (1966). Studies on the Larval Development of the Crab, Rhithropanopeus harrisii (Gould). I. The Effect of Salinity and Temperature on Larval Development. Physiological Zoology, 39(2), 81-100.

Crane, J. (1975). Fiddler crabs of the world (Ocypodidae: genus Uca). Princeton, New Jersey: Princeton University Press.

De Vries, M. C., Tankersley, R. A., Forward, R. B., Kirby-Smith, W. W., \& Luettich, R. A. (1994). Abundance of estuarine crab larvae is associated with tidal hydrologic variables. Marine Biology, 118(3), 403-413.

Epifanio, C. E. (1988). Transport of crab larvae between estuaries and the continental shelf. In: Jansson BO (ed) Coastal-offshore ecosystem interactions, Book 22. Springer-Verlag, Heidelberg.

Estoup, A., Largiader, C. R., Perrot, E., \& Chourrout, D. (1996). Rapid one-tube DNA extraction for reliable PCR detection of fish polymorphic marker and transgenes. Molecular Marine Biology Biotechnology, 5, 295-298.

Forward, R. B. Jr., \& Tankersley, R. A. (2001). Selective tidal stream transport of marine animals. Oceanography and Marine Biology: an Annual Review, 39, 305-353.

Frix, M. S., Hostetler, M. E., \& Bildstein, K. L. (1991). Intra- and interspecies differences in 
responses of Atlantic sand (Uca pugilator) and Atlantic marsh (U. pugnax) fiddler crabs to simulated avian predators. Crustacean Biology, 11, 523- 529.

Miller, K.G., \& Maurer, D. (1973). Distribution of the fiddler crabs, Uca pugnax and Uca minax, in relation to salinity in Delaware Rivers. Chesapeake Science, 14, 219-221.

O’Connor, N. J. (1991). Flexibility in timing of the metamorphic molt by fiddler crab megalopae Uca pugilator. Marine Ecology Progress Series, 68, 243-247.

O’Connor, N. J. (1993). Settlement and recruitment of the fiddler crabs Uca pugnax and $U$. pugilator in a North Carolina, USA, salt marsh. Marine Ecology Progress Series, 93, 227-234.

O’Connor, N. J. (2005). Influence of extracts of adult crabs on molting of fiddler crab megalopae (Uca pugnax). Marine Biology, 146(4), 753-759.

O’Connor, N. J., \& Gregg, A. S. (1998). Influence of Potential Habitat Cues on Duration of the Megalopal Stage of the Fiddler Crab Uca Pugnax. Journal of Crustacean Biology, 18(4), 700-709.

O’Connor, N. J., \& Judge, M. L. (1997). Flexibility in timing of molting of fiddler crab megalopae: evidence from in situ manipulation of cues. Marine Ecology Progress Series, $146,55-60$.

O’Connor, N. J., \& Judge, M. L. (1999). Cues in salt marshes stimulate molting of fiddler crab Uca pugnax megalopae: more evidence from field experiments. Marine Ecology Progress Series, 181, 131-139.

O’Connor, N. J., \& Judge, M. L. (2004). Molting of fiddler crab Uca minax megalopae: stimulatory cues are specific to salt marshes. Marine Ecology Progress Series, 282, 229236. 
O’Connor, N. J., \& Van, B. T. (2006). Adult fiddler crabs Uca pugnax (Smith) enhance sediment-associated cues for molting of conspecific megalopae. Journal of Experimental Marine Biology and Ecology, 335(1), 123-130.

Petit, D. R., \& Bildstein, K. L. (1987). Effect of group-size and location within the group on the foraging behavior of white ibises. Condor, 89, 602-609.

Qureshi, N. A., \& Saher, N. U. (2012). Burrow morphology of three species of fiddler crab (Uca) along the coast of Pakistan. Belgian Journal of Zoology, 142(2), 114-126.

Smith, S. M., \& Green, C. W. (2015). Sediment suspension and elevation Loss triggered by Atlantic mud fiddler crab (Uca pugnax) bioturbation in salt Marsh dieback areas of Southern New England. Journal of Coastal Research, 31(1), 88-94.

Sokal, R. R., \& Rohlf, F. J. (1981). Biometry, $2^{\text {nd }}$ edition. Freeman \& Co., New York, NY.

Teal, J. M. (1958). Distribution of fiddler crabs in Georgia salt marshes. Ecology, 39, 185-193.

Walpole, R. E. (1974). Introduction to statistics, $2^{\text {nd }}$ edition. Macmillan, New York, NY.

Welch, J. M., Reinsel, K. A., Battles, K. A., Romero, A. O., Blaine, J. M., Sendi, R. L., \& Forward, R. B. (2015). Settlement of fiddler crab megalopae on a North Carolina (USA) sandflat: Species identification using multiplex PCR provides evidence for selective settlement. Marine Ecology Progress Series, 523, 115-123.

Welch, J. M., Reinsel, K. A., Waddell, E. E., Wright, A. J., \& Forward, R. B. (2016). Chemical cues from adult fiddler crabs stimulate molting of conspecific megalopae: Evidence from field-caught individuals. Marine Ecology Progress Series, 553, 147-153.

Wolcott, D. L., \& De Vries, M. C. (1994). Offshore megalopae of Callinectes sapidus: depth of collection, molt stage and response to estuarine cues. Marine Ecology Progress Series, $109,157-163$. 
Zhong, H. (2006). Common Florida Fiddler Crabs (*Uca* spp.). Public Health Entomology Research \& Education Center, 10, 1-7. 